\title{
Development and Validation of Liquid Chromatographic Method for Estimation of Ibuprofen and Famotidine in Combined Dosage Form
}

\author{
Dimal A. Shah, Dixita J. Suthar, Sunil L. Baldania, \\ Usman K. Chhalotiya, and Kashyap K. Bhatt \\ Indukaka Ipcowala College of Pharmacy, Phase IV, Beyond GIDC, New Vallabh Vidyanagar, P.B. No. 53,
} P.O. Vithal Udyognagar, Gujrat-388 121, India

Correspondence should be addressed to Dimal A. Shah, dimalgroup@yahoo.com

Received 12 January 2012; Accepted 14 February 2012

Academic Editors: V. L. Cebolla, C. Desiderio, D. J. Fletouris, and W. Misiuk

Copyright ( 2012 Dimal A. Shah et al. This is an open access article distributed under the Creative Commons Attribution License, which permits unrestricted use, distribution, and reproduction in any medium, provided the original work is properly cited.

\begin{abstract}
An isocratic, reversed phase-liquid-chromatographic assay method was developed for the quantitative determination of ibuprofen and famotidine in combined-dosage form. A Brownlee $\mathrm{C}_{18}, 5 \mu \mathrm{m}$ column with mobile phase containing water : methanol : acetonitrile $(30: 60: 10, \mathrm{v} / \mathrm{v} / \mathrm{v})$ was used. The flow rate was $1.0 \mathrm{~mL} / \mathrm{min}$, and effluents were monitored at $264 \mathrm{~nm}$. The retention times of ibuprofen and famotidine were $4.9 \mathrm{~min}$ and $6.8 \mathrm{~min}$, respectively. The linearity for ibuprofen and famotidine was in the range of $2-20 \mu \mathrm{g} / \mathrm{mL}$ and $0.1-10 \mu \mathrm{g} / \mathrm{mL}$, respectively. The proposed method was validated with respect to linearity, accuracy, precision, specificity, and robustness. The method was successfully applied to the estimation of ibuprofen and famotidine in combined dosage form.
\end{abstract}

\section{Introduction}

Ibuprofen (IBU) is chemically (RS)-2-(4-(2-methylpropyl) phenyl) propanoic acid $[1,2]$. The empirical formula of IBU is $\mathrm{C}_{13} \mathrm{H}_{18} \mathrm{O}_{2}$, with a molecular weight of $206.2 \mathrm{~g} / \mathrm{mole}$ (Figure 1). It is a nonsteroidal anti-inflammatory drug, and it inhibits prostaglandin biosynthesis by blocking the enzyme cyclooxygenase, which converts arachidonic acid to prostaglandin. It is used as analgesic, antipyretic, and antiinflammatory drug [3]. Famotidine (FAM) is chemically 3[(\{2-[(diaminomethylidene)amino]-1,3-thiazol-4-yl $\}$ methyl) sulfanyl] $-\mathrm{N}^{\prime}$ sulfamoyl propanimidamide $[1,2]$. It has an empirical formula $\mathrm{C}_{8} \mathrm{H}_{15} \mathrm{~N}_{7} \mathrm{O}_{2} \mathrm{~S}_{3}$ and a molecular weight of $337 \mathrm{~g} / \mathrm{mole}$ (Figure 2). It is a histamine-2 receptor blocker. Histamine stimulates cells lining of stomach to produce acid. Famotidine blocks the action of histamine on stomach cells, thus reducing production of acid by the stomach [3]. The combination dosage form of ibuprofen and famotidine is available in the market, and it is indicated in the treatment of arthritis.

A literature survey regarding quantitative analysis of these drugs revealed that attempts have been made to develop analytical methods for the estimation of ibuprofen alone and in combination with other drugs by liquid chromatographic (LC) [4-7], HPTLC [8-10], supercritical fluid chromatography [11], and spectrophotometric methods [12]. Famotidine is official in British Pharmacopoeia and United States Pharmacopoeia. A literature survey revealed that liquid chromatographic (LC) [13], HPTLC [14] and spectrophotometric methods [15] have been reported for the estimation of famotidine.

There is no method reported for the estimation of IBU and FAM in combined dosage form. The present study involves development and validation of liquid chromatographic method for the estimation of IBU and FAM in combined dosage form. 
<smiles>CC(C)Cc1ccc([C@@H](C)C(=O)O)cc1</smiles>

FIGURE 1: Structure of ibuprofen.

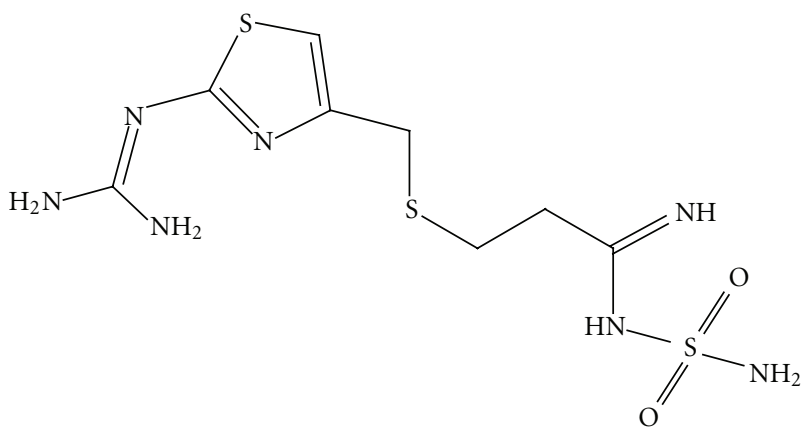

Figure 2: Structure of famotidine.

\section{Experimental}

2.1. Apparatus. The liquid chromatographic system consists of PerkinElmer series 200 LC (Shelton, USA) equipped with a series 200 UV detector, series 200 quaternary gradient pump, and manual injector rheodyne valve with $20 \mu \mathrm{L}$ fixed loop. The analytes were monitored at $264 \mathrm{~nm}$. Chromatographic analysis was performed on Brownlee $\mathrm{C}_{18}$ column having $250 \mathrm{~mm} \times 4.6 \mathrm{~mm}$ i.d. and $5 \mu \mathrm{m}$ particle size. All the drugs and chemicals were weighed on Shimadzu electronic balance (AX 200, Shimadzu Corp., Japan).

2.2. Reagents and Materials. Analytically pure FAM and IBU were obtained as gift samples from Blue Cross Laboratory limited, Mumbai, India, and Mercury Laboratories Limited, Vadodara, India, respectively. HPLC grade acetonitrile, methanol, and water were obtained from E. Merck Ltd., Mumbai, India. Tablet formulation (DUEXIS, Horizon Pharma, USA) containing labeled amount of $800 \mathrm{mg}$ of ibuprofen and $26.6 \mathrm{mg}$ of famotidine was used for the study.

2.3. Chromatographic Conditions. The Brownlee $\mathrm{C}_{18}$ column equilibrated with mobile phase water: methanol: acetonitrile $(30: 60: 10, \mathrm{v} / \mathrm{v} / \mathrm{v})$ was used. The flow rate was maintained at $1 \mathrm{~mL} / \mathrm{min}$, eluent was monitored with UV detector at $264 \mathrm{~nm}$, and the injection volume was $20 \mu \mathrm{L}$. Total run time was kept $10 \mathrm{~min}$.

2.4. Preparation of Standard Stock Solutions. IBU and FAM were weighed ( $25 \mathrm{mg}$ each) and transferred to two separate $25 \mathrm{~mL}$ volumetric flasks and dissolved in few $\mathrm{mL}$ of mobile phase. Volumes were made up to the mark with mobile phase to yield a solution containing $1000 \mu \mathrm{g} / \mathrm{mL}$ of IBU and FAM, respectively. Aliquots from the stock solutions of IBU and FAM were appropriately diluted with mobile phase to obtain working standard of $100 \mu \mathrm{g} / \mathrm{mL}$ of IBU and FAM, respectively.

\section{Method Validation}

The method was validated for accuracy, precision, linearity, detection limit, quantitation limit, and robustness.

3.1. Linearity. Appropriate aliquots of IBU and FAM working standard solutions were taken in different $10 \mathrm{~mL}$ volumetric flasks and diluted up to the mark with mobile phase to obtain final concentrations of $2,5,10,15,20 \mu \mathrm{g} / \mathrm{mL}$ of IBU and $0.1,0.5,1,4,10 \mu \mathrm{g} / \mathrm{mL}$ of FAM, respectively. The solutions were injected using a $20 \mu \mathrm{L}$ fixed loop system, and chromatograms were recorded. Calibration curves were constructed by plotting average peak area versus concentrations, and regression equations were computed for both the drugs.

3.2. Precision. The repeatability studies were carried out by estimating response of IBU $(10 \mu \mathrm{g} / \mathrm{mL})$ and FAM $(1 \mu \mathrm{g} / \mathrm{mL})$ six times, and results are reported in terms of relative standard deviation. The intraday and interday precision studies (intermediate precision) were carried out by estimating the corresponding responses 3 times on the same day and on 3 different days for three different concentrations of IBU (2, $10,20 \mu \mathrm{g} / \mathrm{mL})$ and $\operatorname{FAM}(0.1,1,10 \mu \mathrm{g} / \mathrm{mL})$, and the results are reported in terms of relative standard deviation.

3.3. Accuracy. The accuracy of the method was determined by calculating recoveries of IBU and FAM by method of standard additions. Known amount of $\operatorname{IBU}(0,4,8$, $12 \mu \mathrm{g} / \mathrm{mL})$ and FAM $(0,0.1,1,4 \mu \mathrm{g} / \mathrm{mL})$ were added to a prequantified sample solution, and the amount of IBU and FAM was estimated by measuring the peak areas and by fitting these values to the straight-line equation of calibration curve.

3.4. Detection Limit and Quantitation Limit. The limit of detection (LOD) is defined as the lowest concentration of an analyte that can reliably be differentiated from background levels. Limit of quantification (LOQ) of an individual analytical procedure is the lowest amount of analyte that can be quantitatively determined with suitable precision and accuracy. LOD and LOQ were calculated using following equation as per ICH guidelines:

$$
\begin{aligned}
& \mathrm{LOD}=3.3 \times \frac{\sigma}{S}, \\
& \mathrm{LOQ}=10 \times \frac{\sigma}{S},
\end{aligned}
$$

where $\sigma$ is the standard deviation of $y$-intercepts of regression lines and $S$ is the slope of the calibration curve.

3.5. Robustness. Robustness of the method was studied by deliberately changing the experimental conditions like flow rate and percentage of organic phase. 
3.6. Solution Stability. Stability of sample solutions was studied at $25 \pm 2^{\circ} \mathrm{C}$ for $24 \mathrm{~h}$.

3.7. System Suitability. A system suitability test was an integral part of the method development to verify that the system is adequate for the analysis of IBU and FAM to be performed. System suitability test of the chromatography system was performed before each validation run. Five replicate injections of a system suitability standard and one injection of a check standard were made. Area, retention time (RT), tailing factor, asymmetry factor, and theoretical plates for the five suitability injections were determined.

3.8. Analysis of Marketed Formulation. Twenty tablets were weighed accurately and finely powdered. Tablet powder equivalent to $800 \mathrm{mg}$ IBU and $26.6 \mathrm{mg}$ of FAM was taken in $100 \mathrm{~mL}$ volumetric flask. Methanol $(50 \mathrm{~mL})$ was added to the above flask, and the flask was sonicated for 15 minutes. The solution was filtered using whatman filter paper no. 41 , and volume was made up to the mark with the mobile phase.

Appropriate volume of the aliquot was transferred to a $10 \mathrm{~mL}$ volumetric flask, and the volume was made up to the mark with the mobile phase to obtain a solution containing $12 \mu \mathrm{g} / \mathrm{mL}$ of IBU and $0.4 \mu \mathrm{g} / \mathrm{mL}$ of FAM. The solution was sonicated for $10 \mathrm{~min}$. It was injected as per the above chromatographic conditions and peak areas were recorded. The quantifications were carried out by keeping these values to the straight line equation of calibration curve.

\section{Results and Discussion}

4.1. Optimization of Mobile Phase. The objective of the method development was to resolve chromatographic peaks for active drug ingredients with less asymmetric factor.

The mobile phase water:methanol:acetonitrile $(30: 60: 10, \mathrm{v} / \mathrm{v} / \mathrm{v})$ was found to be satisfactory which gave two symmetric and well-resolved peaks for IBU and FAM. The retention time for IBU and FAM were $4.9 \mathrm{~min}$ and $6.8 \mathrm{~min}$, respectively (Figure 3). The resolution between IBU and FAM was found to be 4, which indicates good separation of both the compounds. The asymmetric factors for IBU and FAM were 1.3 and 0.8 , respectively. The mobile phase flow rate was maintained at $1 \mathrm{~mL} / \mathrm{min}$. Overlaid UV spectra of both the drugs showed that IBU and FAM absorbed appreciably at $264 \mathrm{~nm}$; so detection was carried out at $264 \mathrm{~nm}$.

4.2. Method Validation. The calibration curve for IBU was found to be linear in the range of $2-20 \mu \mathrm{g} / \mathrm{mL}$ with a correlation coefficient of 0.9988 . The calibration curve for FAM was found to be linear in the range of $0.1-10 \mu \mathrm{g} / \mathrm{mL}$ with a correlation coefficient of 0.9972 . The regression analysis of calibration curves is reported in Table 1. Instrument precision was determined by performing injection repeatability test, and the RSD values for IBU and FAM were found to be $0.58 \%$ and $0.47 \%$, respectively. The intraday and intraday precision studies were carried out, and the results

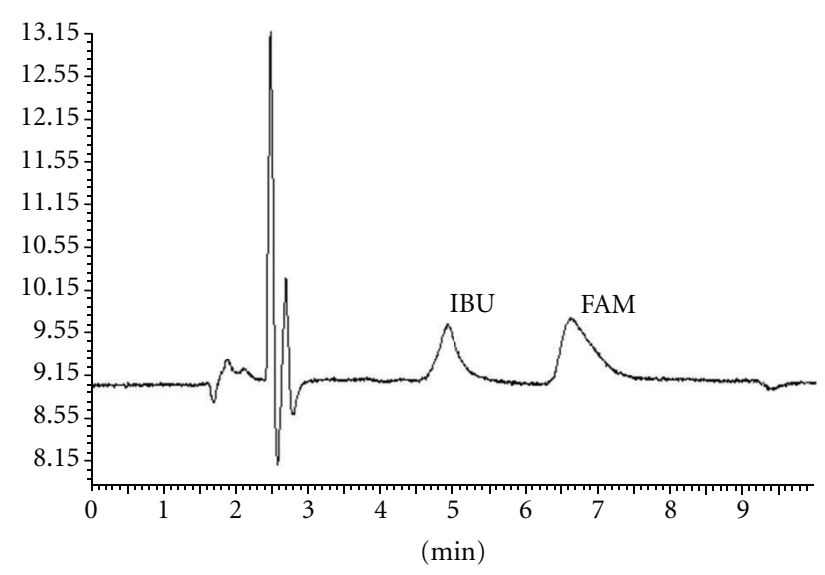

Figure 3: Liquid chromatogram of IBU and FAM.

TABLE 1: Regression analysis of calibration curve.

\begin{tabular}{lcc}
\hline Parameter & IBU & FAM \\
\hline Linearity $(\mu \mathrm{g} / \mathrm{mL})$ & $2-20$ & $0.1-10$ \\
Correlation coefficient $(r)$ & 0.998 & 0.997 \\
Slope of regression & 1973.26 & 25880.80 \\
Standard deviation of slope & 14.97 & 29.47 \\
Intercept of regression & 535.06 & 7544.28 \\
Standard deviation of intercept & 2.96 & 0.30 \\
\hline
\end{tabular}

are reported in Table 2. The low RSD values indicate that the method is precise.

The accuracy of the method was determined by calculating recoveries of IBU and FAM by method of standard addition. The recoveries were found to be $97.60-100.42 \%$ and $99.85-101.47 \%$ for IBU and FAM, respectively (Table 2). The high values indicate that the method is accurate.

The detection limits for IBU and FAM were found to be $0.65 \mu \mathrm{g} / \mathrm{mL}$ and $0.033 \mu \mathrm{g} / \mathrm{mL}$, respectively, while quantitation limits were found to be $2 \mu \mathrm{g} / \mathrm{mL}$ and $0.1 \mu \mathrm{g} / \mathrm{mL}$, respectively. The above data shows that a nanogram quantity of both the drugs can be accurately and precisely determined. Robustness study was performed by deliberately changing the experimental conditions like flow rate from $1 \mathrm{~mL} / \mathrm{min}$ to $0.8 \mathrm{~mL} / \mathrm{min}$ and $1.2 \mathrm{~mL} / \mathrm{min}$. The composition of mobile phase was changed, varying the proportion of methanol by $5 \%$. In both conditions, the recovery of both the drugs was determined and the RSD was found to be less than $2 \%$.

System suitability test was carried out, and the results are summarized in Table 3.

Stability of standard and sample solution of IBU and FAM were evaluated at room temperature for $24 \mathrm{hr}$. Both the drugs were found to be stable with a recovery of more than $97 \%$.

4.3. Analysis of Marketed Formulations. The proposed method was successfully applied to the determination of IBU and FAM in their combined dosage form. The \% recovery was found to be $100.01 \pm 0.72$ and $98.56 \pm 0.37$, 
TABLE 2: Summary of validation parameters.

\begin{tabular}{lcc}
\hline Parameters & IBU & FAM \\
\hline Retention time $(\mathrm{min})$ & 4.9 & 6.8 \\
Detection limit $(\mu \mathrm{g} / \mathrm{mL})$ & 0.65 & 0.033 \\
Quantitation limit $(\mu \mathrm{g} / \mathrm{mL})$ & 2 & 0.1 \\
Accuracy $\%)$ & $97.60-100.42 \%$ & $99.85-101.47 \%$ \\
\hline Precision $\left(\mathrm{RSD}^{\mathrm{a}}, \%\right)$ & & $0.72-0.94 \%$ \\
\hline \multicolumn{1}{c}{ Intraday precision $(n=3)$} & $0.75-0.93 \%$ & $0.92-1.51 \%$ \\
$\quad$ Interday precision $(n=3)$ & $1.02=1.53 \%$ & $0.47 \%$ \\
Instrument precision $\left(\mathrm{RSD}^{\mathrm{a}}\right)$ & $0.58 \%$ & \\
\hline
\end{tabular}

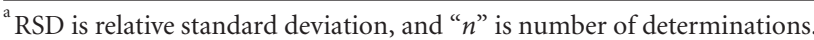

TABLE 3: System suitability parameter for the proposed method.

\begin{tabular}{lcc}
\hline Parameter & IBU & FAM \\
\hline Retention time $(\mathrm{min})$ & 4.9 & 6.8 \\
Theoretical plates & 4560 & 6400 \\
Tailing factor & 1.3 & 0.8 \\
Base width $(\mathrm{sec})$ & 29.49 & 42.22 \\
\hline
\end{tabular}

TABLE 4: Analysis of marketed formulation.

\begin{tabular}{|c|c|c|c|c|}
\hline \multirow{3}{*}{ Formulations } & \multirow{2}{*}{\multicolumn{2}{|c|}{$\begin{array}{c}\text { Labelled } \\
\text { Amount (mg) }\end{array}$}} & \multirow{2}{*}{\multicolumn{2}{|c|}{ \% Recovery }} \\
\hline & & & & \\
\hline & IBU & FAM & IBU & FAM \\
\hline A & 800 & 26.6 & $100.01 \pm 0.72$ & $98.56 \pm 0.37$ \\
\hline
\end{tabular}

respectively, for IBU and FAM (Table 4), which were comparable with the corresponding labeled amounts.

\section{Conclusion}

The proposed study describes stability indicating LC method for the estimation of IBU and FAM combination in mixture. The method was validated and found to be simple, sensitive, accurate, and precise. The method was successfully used for determination of drugs in their pharmaceutical formulation.

\section{Acknowledgments}

The authors are thankful to Mercury pharmaceuticals Ltd., Baroda and Blue Cross Laboratory, Mumbai, India, for providing a gift sample of IBU and FAM, respectively. The authors are very thankful to Principal, Indukaka Ipcowala College of Pharmacy, New Vallabh, Vidyanagar, for providing necessary facilities to carry out research work.

\section{References}

[1] M. J. O'Neil, The Merck Index, Merck \& Co., Whitehouse Station, NJ, USA, 13th edition, 2001.
[2] A. C. Moffat, M. D. Osselton, B. Widdop, and E. G. Clarke, Clarke's, Analysis of Drugs and Poisons in Pharmceuticals, Pharmaceutical Press, Cornwall, UK, 3rd edition, 2004.

[3] H. P. Rang and M. M. Dale, Pharmacology, 3rd edition, 2003.

[4] The Indian Pharmacopoeia commission, Indian Pharmacopoeia Vol II, The Indian Pharmacopoeia commission, Ghaziabad, India, 2007.

[5] The Stationery office, British Pharmacopoeia Vol. IlI, The Stationery office, London, UK, 2009.

[6] United States Pharmacopeial Convention. Committee of Revision, United States Pharmacopoeia and National Formulary, United States Pharmacopeial Convention, Rockville, Md, USA, 27th edition, 2004.

[7] P. B. Reddy and M. S. Reddy, "RP-HPLC method for simultaneous estimation of paracetamol and ibuprofen in tablets," Asian Journal of Research in Chemistry, vol. 2, no. 1, pp. 70-72, 2009.

[8] S. Chitlange, D. Sakarkar, S. Wankhede, and S. Wadodkar, "High performance thin layer chromatographic method for simultaneous estimation of ibuprofen and pseudoephedrine hydrochloride," Indian Journal of Pharmaceutical Sciences, vol. 70, no. 3, pp. 398-400, 2008.

[9] W. D. Sam Solomon, R. A. Kumar, P. R. Vijai Anand, R. Sivakumar, and R. Venkatnarayanan, "Derivatized HPTLC method for simultaneous estimation of glucosamine and ibuprofen in tablets," Journal of Pharmaceutical Research and Health Care, vol. 2, no. 2, pp. 156-162, 2010.

[10] R. V. Rele and S. A. Sawant, "Determination of paracetamol and ibuprofen from combined dosage formulation by HPTLC method," Analytical Chemistry, vol. 9, no. 1, pp. 302-305, 2010.

[11] V. R. Bari, U. J. Dhorda, and M. Sundaresan, "A simultaneous packed column supercritical fluid chromatographic method for ibuprofen, chlorzoxazone and acetaminophen in bulk and dosage forms," Talanta, vol. 45, no. 2, pp. 297-302, 1997.

[12] R. Gondalia, R. Mashru, and P. Savaliya, "Development and validation of spectrophotometric methods for simultaneous estimation of ibuprofen and paracetamol in soft gelatin capsule by simultaneous equation method," International Journal of ChemTech Research, vol. 2, no. 4, pp. 1881-1885, 2010.

[13] S. Najma, A. Mahwish, G. S. Shamim, and Somia, "Determination of moxifloxacin and famotidine in pharmaceutical dosage formulations by RP HPLC: application to in vitro drug interactions," Química Nova, vol. 34, no. 4, pp. 683-688, 2011.

[14] J. Novaković, "High-performance thin-layer chromatography for the determination of ranitidine hydrochloride and 
famotidine in pharmaceuticals," Journal of Chromatography A, vol. 846, no. 1-2, pp. 193-198, 1999.

[15] B. Kanakapura, Z. D. Okram, and J. Pavagada, "Simple and sensitive UV spectrophotometric methods for determination of famotidine in table formulations," Farmacia, vol. 59, pp. 647-656, 2011. 


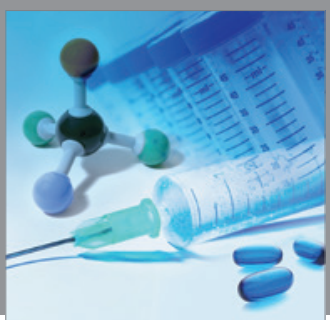

International Journal of

Medicinal Chemistry

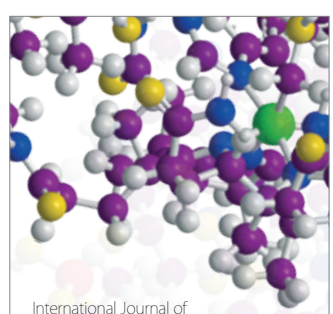

Carbohydrate Chemistry

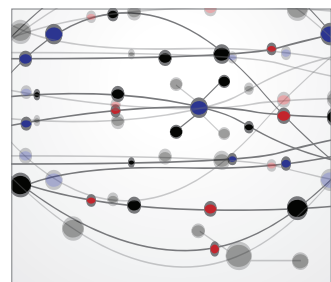

The Scientific World Journal
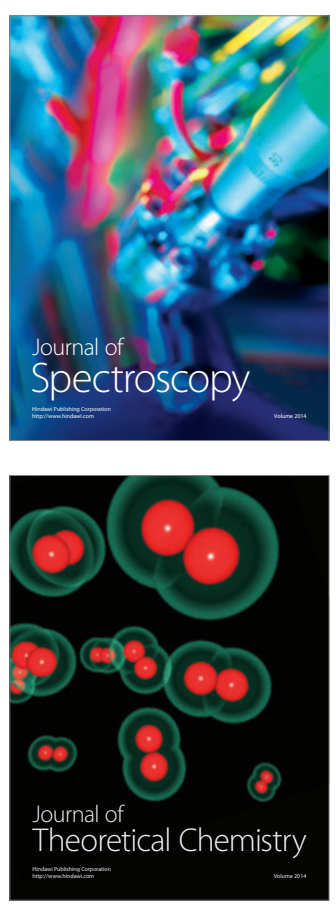
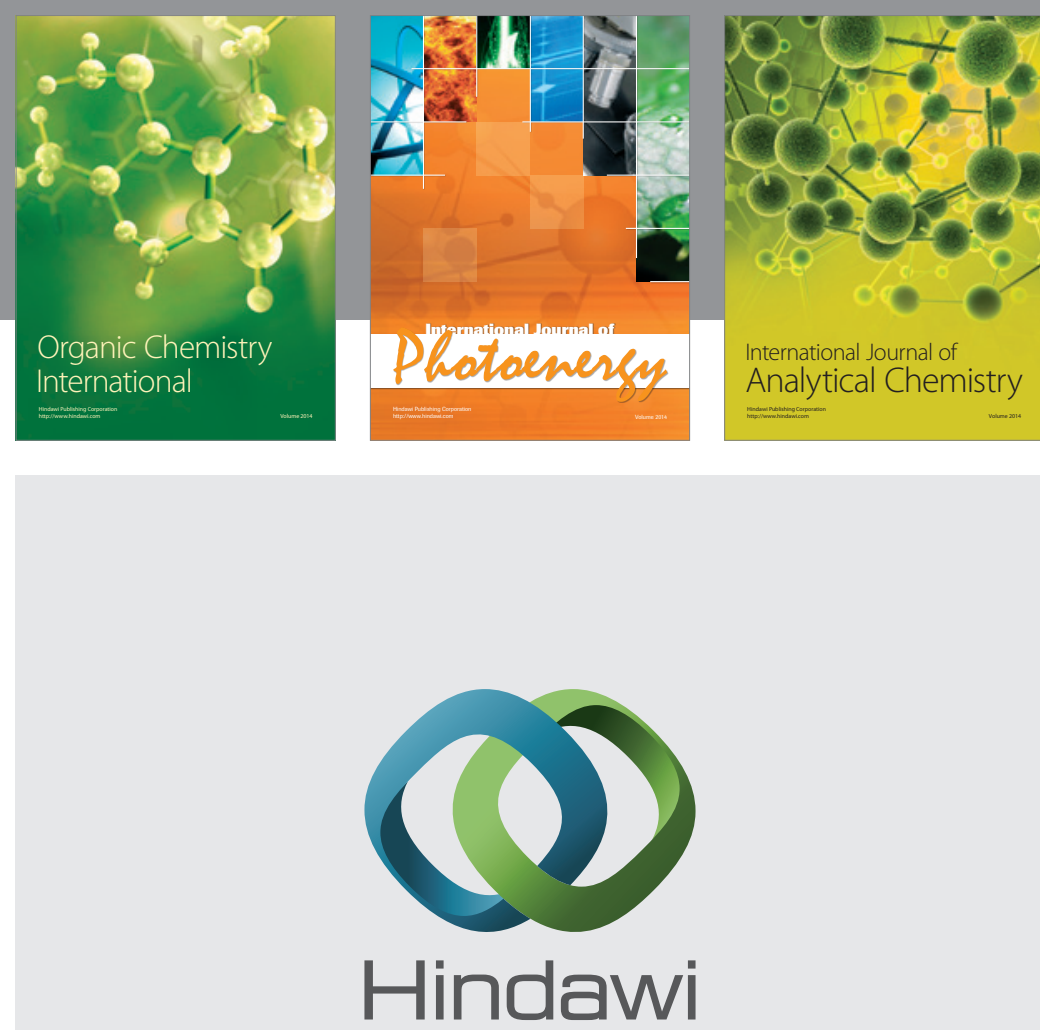

Submit your manuscripts at

http://www.hindawi.com
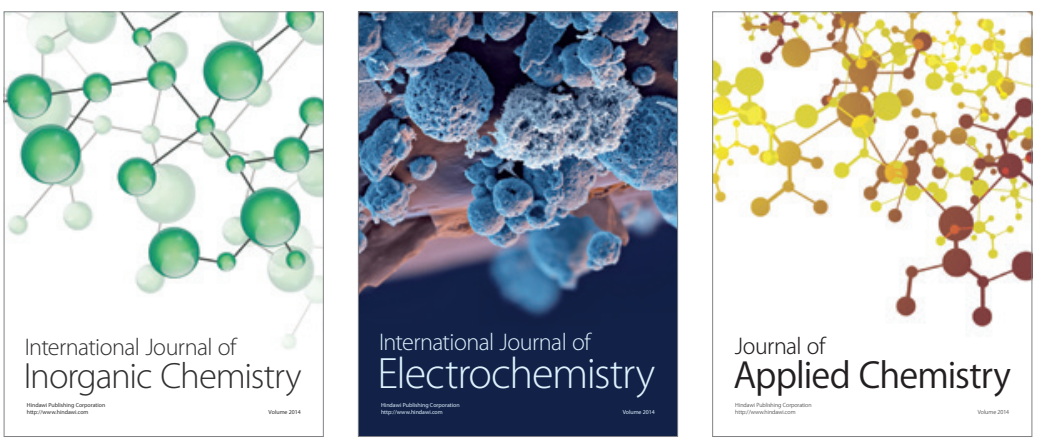

Journal of

Applied Chemistry
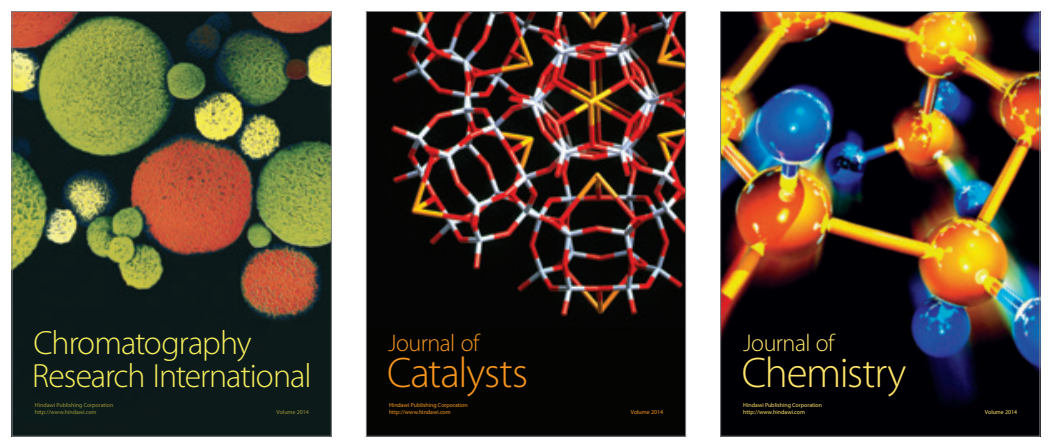
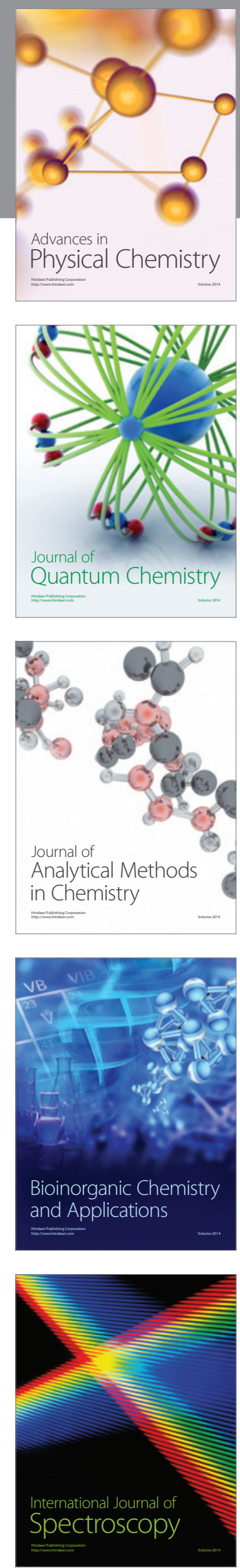